\title{
Brazill and Regional Integration in South America: Lessons from the EU's Crisists*
}

Elena Lazarou**

\section{Introduction}

The academic debate on regionalism and regional integration has been intrinsically linked to the evolution of the European Communities from the 1950s to today. As the earliest and only project of regional cooperation to attain a high level of supra-nationalism, the European project which led to the creation of the European Union (EU) in the early 1990s, has been used as the central empirical object in the study of states' capacity to move from intergovernmental cooperation to full-fledged integration. As such, it has been used as the basis for the development of theory of regional integration but also for po-

\footnotetext{
* Article submitted on September 16th, 2013 and approved for publication in November 1st, 2013.

** Elena Lazarou holds a Ph.D. in International Relations from the University of Cambridge. Dr. Lazarou is Head of the Centre for International Relations of the Getulio Vargas Foundation (FGV) and Assistant Professor at FGV's School of Social Sciences (CPDOC). Her interests include European Studies, Foreign Policy Analysis and Regional Integration. E-mail: elena.lazarou@fgv.br.
}

CONTEXTO INTERNACIONAL Rio de Janeiro, vol. 35, n² 2, julho/dezembro 2013, p. 353-385. 
licy-oriented thinking regarding regional strategizing. Both this theory and policy have expanded across the world, guiding the conceptualization of regionalism across a number of regions.

The idea of "model power" is somehow connected with the academic debates on the nature of the EU's identity as an international player and its influence on international and regional developments across the world. Scholars of European integration (e.g. CEDERMAN, 2001; SMITH, 2003; LUCARELLI; MANNERS, 2006) have introduced various new terms in order to explain the non-material power of the EU. Most famously, the notion of "normative power Europe" conceptualizes the EU as a changer of norms in the international system (MANNERS, 2002, p. 252).

Such a normative dimension lies at the centre of the EU "model" and its evolution since the late 1950s. Moreover, its significant regional achievements have led the EU to perceive itself as an example of effective and legitimate governance, which other countries and regions can and do emulate (TORRENT, 2002). Therefore, the "export" or "diffusion" of norms has become intrinsically linked to the EU's external relations policy, a significant part of which is the promotion of regional integration and cooperation in other parts of the world. Thus, "the ideational impact captured by Manner's notion of normative power Europe (NPE) appears potentially most consequential in the realm of global regionalism" (LENZ, 2013). Nevertheless, the past few years have marked the beginning of a new critical discussion, regarding the transformation of the focus of regional integration studies, moving away from the monopoly of the EU - and the implication that it has been, directly or indirectly, explicitly or implicitly, imitated by most regionalization initiatives across the globe (see FIORAMONTI, 2012).

With these preliminary thoughts in mind, the first part of this paper introduces the idea of the EU as a "model" of regional integration, 
linking it to the literature on Europe as a normative power. The second part discusses the influence of the EU model on regional cooperation and integration in South America. In particular, it focuses on the discursive use of the model in Brazilian foreign policy during the two tenures of former President Luiz Inácio Lula da Silva as the dominant rhetoric for the promotion of regional integration, especially in the case of the Mercado Común del Sur (Common Market of the South, MERCOSUR) and the Unión de Naciones Suramericanas (Union of South American Nations, UNASUR). The last part looks at the impact of the financial crisis on the "deconstruction" of this ideal model of European integration and attempts to discern how this will influence the future discourse on regional cooperation integration in South America, and primarily in Brazil. To illustrate the shift that has occurred in Brazilian views of regionalism, this part also discusses the Brazilian support of a new form of regional integration, as embodied in the creation of CELAC, the Community of Latin American and Caribbean States.

\section{The European Union's Model of Regional Integration}

The concept of regionalism evokes much controversy on many different levels. By and large scholars agree that we are experiencing a transition between an old system and a new one, but the causes and contours of this new system are up for debate (BACCINI; DUR, 2012; POWERS; GOERTZ, 2011; BALDWIN, 2011). Yet so far, in the study of regional integration no entity figures as prominently as the EU. In the prevalent literature on the subject, the European integration project is oftentimes used as the key example for the building and testing of theories explaining why states choose to integrate (e.g. HOFFMAN, 1966; LINDBERG, 1963; HAAS, 1963; MO- 
RAVCSIK, 1991) and even as the basis for the examination of the overall logic of regional integration (MATTLI, 1999).

Until recently, scholarly research on regionalism has developed along two lines of thought. On the one hand, social scientists (predominantly economists) have interpreted regional integration as a form of wealth (re)distribution, often coupled with adjustments to the welfare state due to increasing globalization. Thus, their approach to regional cooperation has been influenced by the developments of international trade liberalization and growing interdependence (VINER, 1952; BALASSA, 1961), a view which is still predominant in the social sciences literature (CHRISTIE, 2002; MATTLI, 1999; EICHENGREEN, 1992).

Political scientists, on the other hand, have put forward an approach that focuses on the policy and institutional dimensions of regionalization. Within this context, they have emphasized the importance of the EU as a supranational formation leading its member states towards greater integration and policy coordination (BELLAMY; CASTIGLIONE, 1998). As a result, the particular form of cooperation promoted by the EU has produced deep regionalism within its realm, increasing the states' willingness to sacrifice a degree of sovereignty in order to harmonize, coordinate and integrate policies (HAAS, 1963; LINDBERG, 1963; LAFFAN, 1998).

What makes the EU unique is the economic, political, social and arguably ideational "fusion" of most member states' policies. It is certainly the only case of functional regional integration involving supranational governance, shared competencies and a pooling of sovereignty (KEOHANE; HOFFMANN, 1991). While common markets and customs unions are less uncommon, the EU has evolved from that level into a political community with its own institutions, legal system, policies, values and principles. The process of "spillover" through which this has occurred is perhaps the key to the model's uni- 
queness. ${ }^{1}$ Due to the resulting ever-closer integration, the (now 28) EU member states have moved from sharing a Common Market, to forming a Single Market, involving the free movement of people, goods and services. Moreover, in 1992 the Maastricht Treaty introduced the EU citizenship that, alongside national citizenships, provides the citizens of the member states with additional rights and obligations.

Another significant characteristic of the EU model lies in the transference of sovereignty from national decision-makers to the supranational and intergovernmental institutions headquartered in Brussels. Those institutions, governed by the principles and procedures enshrined in EU law (especially the founding treaties), enact policies exhibiting the "particular" characteristics and norms embedded in the Union itself as a political community. In addition, the increasing empowerment of supranational institutions (e.g. the European Commission and European Parliament) in high politics areas such as foreign affairs contributes to defining the EU as a single player in the international arena and as an aspiring global power, even more so since the enactment of the Lisbon Treaty in 2009, which established the role of President of the European Council and High Representative for Foreign Affairs and Security Policy.

The achievement of such high levels of economic and political integration alongside the maintenance of widespread prosperity has been a key element shaping the EU's identity in the international system and in the projection of its "power". Thus, in recent years, the debate on the EU's capacity to "export" its own model has been largely influenced by a general reconsideration of the nature of power itself in a continually transforming international environment (BICCHI, 2006; PENKETH, 2007; SJURSEN, 2006).

Indeed, while the centrality of power in relations among states and international players is unquestioned, the definition of the concept 
has undergone significant reconsiderations as new developments in the international arena have eroded the classical understanding of power as military might. In this spirit, Joseph Nye has coined the term "soft power", involving ideational rather than material elements, as "the ability to achieve goals through attraction rather than coercion $[\ldots]$ by convincing others to follow or getting them to agree to norms and institutions that produce the desired behavior" (NYE, 2004, p. 86). While Nye's work drew predominantly on the "soft power" of the United States (US), scholars of European integration, and particularly those engaged with the EU's foreign policy and identity as an international player (CEDERMAN, 2001; SMITH, 2003; LUCARELLI; MANNERS, 2006; SJURSEN, 2006), introduced a new terminology to describe the influence the EU exerts in global affairs. Following the original formulation of François Duchêne (1972), who described Europe as a "civilian power", new labels have come to include "ethical power" (AGGESTAM, 2008), "post-modern power" (KIM; PASSONI, 2010), "quiet superpower" (MORAVCSIK, 2009) and, most famously, "normative power" (MANNERS, 2002). According to Ian Manners, the EU as a normative power has an ontological quality (that the EU can be conceptualized as a changer of norms in the international system), a positivist quality (that the EU acts to change norms in the international system) and a normative quality (that the EU should act to extend its norms into the international system) (MANNERS, 2002, p. 252).

The ideas of "soft", "civilian" and "normative" power have been used with particular intensity in the quest for Europe's identity as an player in the international system. It has been argued that the EU's foreign policy derives directly from the very nature of the EU itself and its original telos, which is the ambition to achieve long-lasting peace through integration (SMITH, 2003). This inherent principle places particular emphasis on multilateral cooperation, the primacy of diplomacy (as opposed to coercion), the use of mediation to resolve 
conflicts and the promotion of human rights and the rule of law (KEUKELEIRE, 2010).

Accordingly, the way in which the EU makes and implements its foreign policy is not only "reflected in the content of the policy produced" (SMITH, 2003, p. 18) but also in the legacy and achievements of the EU itself. In this vein, the norms and values that characterize the EU are also promoted and diffused through a series of agreements and partnerships with third countries or groupings of states. Engagement with the latter groups has significantly increased in the past three decades, as part of the "new regionalism" agenda, which carries with it a strong component of external region-to-region engagement, introducing new dynamics to international relations.

Besides trade, diplomacy and economic cooperation, the promotion of regional integration initiatives in other areas of the world is among the most important external policies through which EU directly or indirectly attempts to increase its soft power (SMITH, 2003; LENZ, 2008). Such a focus on regionalization is not a mere projection of the EU's experience, but it is viewed as a key goal to reform international relations. For example, both the European Security Strategy and the Report on its implementation emphasized the necessity to promote regional organizations and processes as key cornerstones of a safer and better organized system of global governance (EUROPEAN COUNCIL, 2003; 2008).

In the promotion of regional cooperation/integration in other parts of the world, the EU's normative power manifests itself through its ability to influence the political, economic and social institutions by means of persuasion and attraction rather than coercion. In this vein, it has been argued that the source of this persuasion/attraction is the appeal of the EU model itself as an example of successful regional integration (LENZ, 2008; SMITH, 2003). For instance, Fawcett and Hurrell (1995) maintain that the logic of interregional cooperation, 
that is the way in which the EU carries out its relations with other regions or groups of states, derives from the success of the European model, which has transformed relations between formerly warring parties into a cooperative structure where divergent interests converge through negotiation and commonly agreed upon institutions. Thus, the EU has been promoting regional integration largely by "exporting" its own model and norms to other regions, which is also evidenced by the emphasis given to the promotion of regional cooperation in the EU's interregional agreements and partnerships with key regional powers (TORRENT, 2002; TELÒ, 2007).

\section{The Relevance of the EU Model in Brazil's Regional Policy}

Regional integration in South America took off with the creation of MERCOSUR - the Common Market of the South - through the Treaty of Asuncion in March 1991 by a joint decision of Argentina, Brazil, Uruguay and Paraguay. MERCOSUR constitutes a customs union and free trade area, which, among other institutions, maintains its own executive institution (Common Market Group) and a decision-making body comprised of national ministers (Common Market Council).

The first years of MERCOSUR coincided with a gradual shift in Brazilian foreign policy towards the region: while previously Brazil had put very little effort in promoting the idea of complex interdependence in the region, in the post Cold-War era regionalism became increasingly more important for the Brazilian foreign policy agenda, reaching its peak during the Lula governments between 2003 and 2010 (SPEKTOR, 2010). Strategically, it has been argued, this reorientation aimed at consolidating Brazil's leadership in the region (SOUTO MAIOR, 2006). At the level of political discourse, this shift implied a rather enthusiastic endorsement of the European international pro- 
ject as the key reference point for South American integration, largely based on the former economic, political and social achievements (LENZ, 2008).

As the undisputed leader in regional initiatives, due largely to its economic size and power, Brazil has often looked to Europe in its discursive construction of an institutional project for its region. President Lula and his Foreign Minister, Celso Amorim, made European-style integration in South America a key goal. As early as his first speech after being elected in 2002, the Brazilian President made it clear that commercial agreements between regional blocs would be a foreign policy priority, thus echoing the EU's traditional preference for interregional trade (ASSIS; MACHADO DA COSTA JR., 2003). In this regard, not only would MERCOSUR need more integration internally, but it would also need to look strategically at the rest of the world to seal new partnerships, including in Africa and the Middle East. Soon after the new government's formation, Foreign Minister Celso Amorim made explicit reference to the EU-model by arguing that MERCOSUR's “agenda of stronger ties in regional integration is a multifaceted project, similar to the European Union" (AMORIM, 2003):

It is important to recognize that the most successful processes of integration existing today had as their primary foundation the strengthening of their legal framework and institutions. The European Union experience proves the importance of seeking to harmonize the set of rules of the member states relating to the integration process at the regional level (AMORIM, 2004a).

Brazil has also been ardently supporting the creation of a directly-elected Parliament of MERCOSUR, echoing concerns generated in Europe regarding the lack of legitimacy and representation in regional organizations (NUNES, 2010). In 2006 MERCOSUR's Jo- 
int Parliamentary Committee was formally replaced by a Parliament, also thanks to the technical and financial support provided by its European counterpart. Yet, due to the inability of MERCOSUR's member states to agree on issues of proportionality and representation, there has been significant delay in making this new institution operational.

Perhaps most ambitiously, Brazil has viewed MERCOSUR as a part of a larger South American integration vision, wider and deeper than the existing Common Market of the South. Seeds of this project were already sown by Itamar Franco's government (1992-1995), which pursued negotiations on the South American Free Trade Area and culminated with the creation of the South American Community of Nations in 2004, renamed as the UNASUR in 2007. Also this sequence followed in the footsteps of the EU, which linguistically moved from being a Community to becoming a Union in 1992 with the objective of underlining a deeper degree of integration.

UNASUR incorporates 12 member states and aims, among other things, to collectively address cultural, social, economic and political issues, including social policies, energy, infrastructure, environment, the reduction of inequalities and the promotion of peace, and democracy. Similarly to the EU, it is institutionally equipped with sectoral ministerial councils to address special areas such as drug trafficking, defense, development, infrastructure and energy. Another important institution for further regional integration that has enjoyed significant Brazilian support has been the Latin American Bank for Regional Development, which is strongly influenced by Jacques Delors' policies for cohesion and regional development, and is reminiscent of the European Central Bank.

A 2010 address by Celso Amorim's to the MERCOSUR Parliament reveals ideas and processes drawn from the EU model, which are often framed in the classic EU language: 
In nearly eight years of President Lula's tenure, Brazil has invested in a new concept of regional integration. A concept that, without disregarding the economic and commercial aspects, seeks to incorporate the political, social and cultural dimensions and, most importantly, a strong sense of solidarity (AMORIM, 2010, p. 2, author's translation and emphasis added).

Besides a clear social agenda, Amorim also envisions a MERCOSUR "which is not only the MERCOSUR of economies or of states, but also the MERCOSUR of the people" (AMORIM, 2010, p. 7, author's translation and emphasis added).

Even here, of course, the EU's model is clearly providing the background, not only with the evolution that eventually led to the direct election of the European Parliament in 1979, the institution of the Ombudsman and the popular initiative legislation, but especially with the debate over the Constitutional Convention of 2004. Although these general concerns are common to any polity, it is only after a certain level of integration that they begin to emerge. In this regard, it is clear that Amorim and Lula's government have been thinking of the future projections of MERCOSUR along the lines of the step-by-step process outlined in the introduction, whereby a common market should evolve into some type of economic and political union.

In terms of external relations, particularly regarding the engagement of MERCOSUR with the wider international community, the government's discourse appears to be influenced by the EU's strategies of interregionalism, engagement with the developing world, democracy promotion and special relationships with the neighbourhood. Brazil has been supporting the conclusion of negotiations on services with Colombia, investments with Chile and the deepening of the MERCOSUR-Peru agreement, while at the same time proposing 
more favorable trade terms for certain Bolivian products, such as textiles. It also emphasizes the need for support, and aid for peace-building and reconstruction in those of the "sister countries" which are going through difficult times, such as Haiti. Both these elements are reminiscent of the EU's policy in the Mediterranean, previously illustrated in initiatives such as the European Neighborhood Policy. Moreover, the preservation and consolidation of democracy in the region is crucial and central in the MERCOSUR vision as presented by Brazil, indicating at the same time the aspiration for MERCOSUR to be more than a trade organization, and resemble a political entity in the making.

Nevertheless, while bearing noticeable similarities to the EC/EU in terms of its economic and trade objectives, MERCOSUR is four times larger than the EU in geographical territory and is comprised of only 4 members. Venezuela's controversial full membership has been pending since 2005 and was only completed in 2012, while Bolivia is in the process of becoming a full member since December 2012. Chile, Colombia, Ecuador and Peru have only been granted associate status. Both for scholars but also for pro-integration policy makers in South America the ongoing challenge for the evolution of MERCOSUR has been to draw on integration "lessons" from Europe - on which most regional integration theory - and adapt them to the particular needs of the continent, such as development and poverty alleviation. In this regard, it is interesting to note that the EU remains a key reference point even in the analysis of MERCOSUR's weaknesses

About the difficulties in South American inte-
gration, such as free circulation among coun-
tries [...] there must be an understanding that
MERCOSUR is just like the European Union
was many decades ago. We are trying to grow
fast, but evidently [we] do not have, yet, almost 
fifty years of existence. So, $[\ldots]$ we try to do "fifty years in five" (AMORIM, 2004b).

Speaking about the creation of UNASUR on national radio, Lula himself addressed preoccupations about internal differences among the South American states by referring to the fact that the European states too often disagreed about important matters, such as Iraq, the constitution and the monetary union. Yet, he concluded, that never led to a rupture of the EU or a threat to its existence (RADIOBRÁS, 2008).

The next section reflects on whether the EU model is still viewed as viable and attractive to Brazil after the breakout of the Euro-crisis and the resulting internal disputes.

\section{The Impact of the Euro-crisis on Brazilian Views on Regional Integration}

Although the turn of the millennium ushered the EU into a consolidation phase, it also revealed more or less hidden weaknesses and, on various occasions, posed several challenges to the deepening of the integration process. Legitimacy and effectiveness crises hit the European Communities and then the EU several times during its life. In 2005, the proposed Constitution was rejected by the French and Dutch referenda. Finally, since 2008 (and more prominently since 2010), the EU's common currency, the Euro, has been under attack due to the risk of sovereign debt default by some member states hit by the global economic crisis. Talks of potential disintegration of the Union, or at least of the Eurozone, have abounded, and solidarity within the EU has reached unprecedented lows.

The explosion of the financial crisis in Europe led to high levels of unemployment, a drop in structural growth and excessive levels of 
sovereign debt. Moreover, an ageing population and increasing dependence on resources have aggravated the crisis. Since the crisis hit member states unevenly, with some countries faring rather well and others sinking into a protracted recession, the implications for the stability and solidarity of the integration process were inevitable. In less than two years, the gap between donors and recipients within the EU grew, bringing with it pessimistic forecasts about the future of regional integration and a lack of support for the EU in many member states.

With the EU emerging as one of the most hard-hit casualties of the financial crisis and with intra-EU inequalities reaching unprecedented peaks, new doubts were raised as to the capacity of Europe to provide leadership in a fundamentally changed international order. As maintained by the Prime Minister of Turkey, one of the so-called emerging economies along with other powerhouses such as China, India and Brazil, "the financial crisis has laid bare Europe's need for greater dynamism and change":

European labor markets and social-security systems are comatose. European economies are stagnant. European societies are near geriatric. Can Europe retain power and credibility in the new world order [...]? (ERDOGAN, 2011).

At the same time, this development began to cast a shadow over the alleged success of an economic and political union without a central government, over the real state of the widely heralded "solidarity" principle at the basis of the EU integration experiment and, overall, about the actual benefits of European integration for its citizenry. ${ }^{2}$

By contrast, just like most emerging powers, Brazil got over the financial crisis quite quickly and with relatively minor shocks. The recession only hit the Latin American country for five months in 2008-2009, largely due to the panic triggered by the financial mar- 
kets. In 2008 the Ibovespa index hit the ground slightly below the 30000 points, creating losses worth billions for major Brazilian companies like Sadia and Votorantim. In response, the Brazilian Central Bank injected millions of dollars into the market; unlike the US and Europe, however, no bail out for national companies was needed. The government decided to temporarily suspend the tax on industrial products in the hope of keeping the Brazilian consumers in the game and helping the automobile industry. With these measures in place and having registered 61 months of continuous growth until the crisis hit, Brazil managed to achieve an average of growth rate over $3.5 \%$ of GDP. Due to its relatively low interdependence with the rest of the world, the whole of Latin America emerged relatively unscathed from the crisis. Thus, while Europe's downward spiral continued, particularly after the 2009-2010 Greek debt crisis, Latin America slowly but steadily gained credibility in international economy. The cover of a 2010 issue of The Economist (NOBODY'S..., 2010b) depicting the world upside down under the heading "Latin America: Nobody's backyard" drew stark comparisons with a suffering Europe, discussed in a previous issue titled "Can anyone perk up Europe?", which portrayed a bent Eiffel Tower (CAN ..., 2010a).

Within this context, two main narratives - questioning the success of regional integration a la EU - emerged out of an analysis of post-crisis discourses among Brazilian policy makers and opinion leaders.

\section{The era of Rising Powers}

Brazilian policy makers and opinion leaders have interpreted the EU crisis as further evidence of the power shift and global transformations occurring in the 21 st century. In its most classical formulation, these changes affect the global economy and give birth to a new international arena in which emerging economies such as Brazil become the new poles of power. This idea has been one of the cornerstones of Lula's foreign policy, as illustrated by the following excerpt from a 
speech delivered at the 2008 G20 Finance Ministers' meeting in Sao Paulo:

We need to enhance the participation of developing countries in the decision mechanisms of the global economy. We must re-assess the role of the existing organisms or create new ones, in order to strengthen the supervision and regulation of financial markets (LULA DA SILVA, 2008a).

The emergence of Brazil and other new player as economic powerhouses of the $21^{\text {st }}$ century is therefore associated with the need to reform global governance. In this context, the crisis is viewed as an opportunity to fast-forward necessary reforms. In a 2010 interview, Minister of Finance, Guido Mantega (2010) stated:

The European crisis did not get in the way [of the reform of multilateral organizations], quite the contrary. The European crisis puts forward the need of continuing the reforms and measures that were established. [...] the European crisis establishes the need of the G20 existence (MANTEGA, 2010).

Lula himself drew the link between the crisis and global reforms by arguing:

We need new governance, one more open to participation. Brazil is ready to take on its responsibility. This is not the time for narrow nationalisms [or] for individual solutions. It is the time for a pact between governments to create a new global finance architecture, capable of promoting safety and development on an equal basis for all [...]. We need to enhance the participation of developing countries in the decision mechanisms of the global economy (LULA DA SILVA, 2008a). 
Although the redistribution of political and economic weight in global affairs preceded the fall of Wall Street and the Euro-crisis, these latter have accelerated the need for a new direction: "in so far as the crisis appeared in the centre of capitalism, big developing countries have become, in a way, guarantors of the world's stability. In this crisis, they are a part of the solution, not of the problem" (AMORIM, 2009).

References to groups like IBSA (India, Brazil and South Africa), the G20 or the BRICS (Brazil, Russia, India, China and South Africa) and their expanding influence have also become more common. The official discourse revolves around the fact that "this time, the emerging countries have helped to re-establish balance in the developed countries. [...] Emerging countries are contributing more than the others to tackle the crisis" (MANTEGA, 2010). Quite importantly, this shift has its epicenter in Europe, where the sovereign debt crisis has revealed a reversed trend: it is now for Brazil to help Greece "get out of its crisis" (AMORIM, 2010).

Interestingly, also the evolution of regional cooperation and integration is affected by the global power shift. MERCOSUR, for instance, figures prominently in Brazil's agenda for global reforms. According to the former president,

MERCOSUR, together with our friends of Latin America and the Caribbean, cannot passively watch the global crisis debate. We have an important role to play in the construction of a new political and economical architecture, of international, multipolar and multilateral dimensions (LULA DA SILVA, 2008b).

While Brazil is increasingly viewed as a forward-looking rising star, Europe is perceived as facing deep challenges that could jeopardize its position in the world economy. At least in the economic realm, the 
Brazilian model seems to have surpassed the EU model. Lula himself referred to this dynamics:

Brazil was one of the last countries to be hit by the crisis and one of the first to recover from it. Why? Because we had reorganized the economy along solid foundations, based on growth, stability, productivity, on a healthy financial system, on the access to credit and on social inclusion. And when the effects of the crisis began to reach us, we strengthened, without hesitation, the basis of our model (LULA DA SILVA, 2010).

In short, it is plausible to conclude that the crisis has helped Brazilian policy makers underline the power shifts and global transformations empowering the Latin American region and weakening traditionally dominant players, particularly Europe. The crisis is thus portrayed as a factual confirmation of the "era of Brazil" rhetoric, as captured in an interview Lula gave to the Spanish daily El Mundo in 2009:

I am convinced that the $21^{\text {st }}$ century is the century of Brazil. We are living an exceptional moment. Despite the crisis, we are creating, this year, more than 1,4 million new formal jobs, while millions of work positions were and are being sacrificed in the rich countries (LULA DA SILVA, 2009).

\section{The EU's crisis: A failure of deep integration?}

Although the overall discourse depicts a rapidly changing world in which Brazil and the Latin American region become more influential and traditional powers such as Europe lose leadership, Brazil and the EU are still described as important partners (e.g. a bilateral strategic partnership was signed in 2007), which should work together toward ending the crisis. Within the new global context, however, Brazil fe- 


\section{Brazil and Regional Integration in South \\ America: Lessons from the EU's Crisis}

els entitled to turn things around and give lessons to Europe, following Amorim's remark that "the European Union is now seeking Brazil's partnership", rather than the other way around (PAIVA, 2008).

The major Brazilian daily, Folha de S. Paulo, refers to a European "Lost Decade", drawing a gloomy parallel with the Brazilian economic crisis of the 1980s (FREIRE, 2011). "What they are living through is very similar to what we lived through in the 1980s. This crisis is one of long duration", writes prominent journalist Miriam Leitão, who concludes that "Europe will have to perform a major restructuring of its debts, as we did here in Brazil" (LEITÃO, 2011). The idea that Europe must learn from Brazil, which to an extent reverses previous patterns of thinking, is welcomed with an underlying sense of achievement and pride, as illustrated in an op-ed by prominent journalist Paulo Nogueira Batista Jr. (2010):

The dynamics that lead to these situations is an old acquaintance of us here in Latin America. In this matter, modesty aside, we could even export some know-how to the Europeans, who had not experienced such a regional dimension crisis for a while. [...] Brazil is well. We are going to lend money to Greece, via the IMF.

Indirectly, these discussions express doubts about the capacity of Europe to stay on course and a general criticism against the behavior of traditional powers. In Lula's words, "the crisis was born in the advanced economies. It is the consequence of blind belief in the auto-regulation capability of markets and, in great measure, of the lack of control over the activities of financial agents" (LULA DA SILVA, 2008a). Some point out that many European countries, especially the so-called PIIGS, lived with an illusion of prosperity, "financing themselves at low cost by adopting the Euro as currency and living under the shelter of the European Central Bank" (DESORDEM..., 
2011). As pointed out by Holden in this volume, these critiques draw attention to the perils of integration, particularly of monetary union, for weaker and poorer states, suggesting more caution is needed when considering "how much" to integrate.

This in turn leads to various claims that the EU as a whole no longer deserves the place of power it occupies in the international system. In the words of Roberto Jaguaribe, Brazilian Ambassador to London:

Europe has suffered important losses in its power and significance. It does not seem reasonable that European countries with proportionately important economies keep superior shares of global governance institutions than countries with much bigger economies. There needs to be a correction (GALLAS, 2010).

The feeling that the EU currently weighs more in global governance than it should and that it may need to be resized in the global reshuffling of roles and power feeds into the Brazilian objective of achieving a reform of global multilateral organizations. Describing the Brazilian view on the much-needed reforms of global governance, Mantega (2010) comments: "We see that Europe is losing its expression. What is the reform about? It is about reducing the participation of advanced countries, that are less dynamic, and enhancing the emerging countries, that are more dynamic".

The decline of Europe, which remains a key commercial and political partner of Brazil, is also perceived as a threat. "From our point of view", writes Leitão (2011), "the ideal scenario is for Europe to manage its crisis the sooner the better, since the region is a great partner of Brazil.” In a 2010 interview Mantega (2010) also expressed concerns that "if European economies grow less, it means that they will import less Brazilian products". 


\section{Brazil and Regional Integration in South}

America: Lessons from the EU's Crisis

Thus, while tendencies to regard the crisis as a failure of the European approach and a success for Brazil, economic interdependence and - to a certain extent - political partnership with the EU counterbalance triumphalism regarding the decline of Europe. Thus, the final assessment is more nuanced than a generic analysis may suggest. Due to contrasting dynamics and more self-interested preoccupations, it seems fair to argue that Brazil views the impact of the EU crisis on its prospects of economic leadership and regional integration with "mixed feelings".

\section{CELAC: A Different Model for Regional Integration?}

Some conclusions regarding a new approach towards regional integration on Brazil's behalf can be drawn by its full support - in 2010 of the creation of CELAC. CELAC was created in 2010 as a new mechanism of consultation for political and integration affairs, including 33 countries in Latin America, Central America and the Caribbean. Its main "designers" were Brazil and Mexico. According to some views, it represents a quest for a new kind of regionalism, with the ability and flexibility not only to overcome some of the region's most enduring disagreements, but also to develop a common voice for the continent in key areas, which would help achieve the regions' goals and increase its international insertion (FAGUNDES, 2010). The Brazilian government described its views regarding CELAC as a mechanism to contribute to the enhancement of political dialogue, as well as to the creation of cooperation projects for Latin America and the Caribbean. Through its engagement with CELAC, it claims to pursue the formation of a regional identity, as well as common Caribbean and Latin American positions on integration and development.

CELAC is a union of two previous initiatives: the Rio Group and CALC (Cúpula América Latina e Caribe sobre Integração e Desenvolvimento). In the 2011 Caracas Summit, CELAC officially inheri- 
ted all the agreements of its predecessors (ITAMARATY, s/d). Interestingly, CELAC has a significant political dimension: it inherited the 19 dialogue partnerships established through the Rio Group. ${ }^{3}$ One of the political objectives of CELAC is to weaken the influence of the United States in the area, creating an alternative body to the Organization of American States (OAS), historically dominated by the US. Thus CELAC was conceived as the vehicle through which Latin America would express its positions on the main debates regarding the international community, and the norms and rules that govern it, as well as regarding transnational challenges. One of CELAC's main roles is to be the voice of Latin America and the Caribbean towards other players, but also in the engagement with multilateral and regional organizations. In July 2013, the first meeting of CELAC's social affairs committee ministers defined that another key part of the organization's goals would be the development of a common agenda for the fight against poverty in the region.

One of the main points of departure from previous integration processes in the region to CELAC is in the abandonment of the open regionalism model as a priority of the integration efforts, replaced by a new form of regionalism and association. There seems to be considerable consensus on the need for a new model of integration in the region, one that links political cooperation with the preservation of sovereignty, rather than with commercial integration. This second phase of the regional integration process has been referred to as "post-liberal regionalism", redirecting the main goals from economic integration and market liberalization to political alignment (SERBIN, 2011). This moves away from the neofunctionalist EU model. At the same time, it carries with it fundamental assumptions regarding sovereignty and its undisputed nature. This new regionalism is more clearly expressed through the construction of resistance blocs (JARAMILLO, 2011). Therefore, there is general consensus among analysts that a new form of regionalism has emerged, in which eco- 


\section{Brazil and Regional Integration in South}

America: Lessons from the EU's Crisis

nomic aspects are secondary to political ones and sovereignty has assumed a fundamental role. This new type of regionalism points to a new set of functions, such as: building consensus; raising the number of players involved in the actions promoted; promoting flexible institutional goals, which allows the participation of a diverse set of players; democratizing the decisions involving international public goods; developing new webs of linkage on specific themes.

In her speech during the CELAC launch summit, Brazilian President Dilma Roussef affirmed that CELAC is a demonstration of the countries' own capacity to look at themselves and identify the geopolitical and strategic importance they have in the region. Interestingly, the Brazilian leader cited Europe's difficult moment and growing fears that the EU might disintegrate, as an indication that the response needs to be a new paradigm, based on social justice and inclusion. Of course, there are significant challenges to the success of CELAC, including the need to achieve balance between cooperation, sovereignty and solidarity; the generation of opportunities for development; the establishment of mechanisms that allow for the construction of a Latin American and Caribbean identity; establishing effective decision making processes; and defining an approach towards institutionalization (ARAVENA, 2012).

But the departure from the certainty that the EU model is the way to go, as incorporated in the rhetoric and practice of the Brazilian endorsement of CELAC, can be interpreted as an indication of an era of reconsideration of so the called "best practices" or models of integration, whether from the EU or elsewhere.

\section{Conclusions}

Throughout the past decade, the EU has served as an example and a model in Brazilian official discourse on regional integration and inter-regionalism. However the outbreak of the Euro-crisis in 2008 has 
severely challenged the appeal of this model in terms of its sustainability and utility as an instrument of regional cooperation. As a consequence, perceptions of the European integration in Brazilian foreign policy have undergone substantial change, casting doubts on the appropriateness of EU-style integration for the Latin American continent. Disillusionment with the European integration ideal of an ever-closer union, will most likely lead Brazil to a more cautious approach to monetary, if not also political, integration in the region. Lula's 2008 suggestion that South America is heading towards a common currency (RADIOBRÁS, 2008) is not likely to resurface anytime soon.

As has been shown, the crisis in Europe, with the resulting internal divisions among Member States, has been viewed by Brazil through the lens of global transformations and a power shift from North to South, thus corroborating the thesis that as Brazil and other new players rise, old powers decline.

At the same time, the attractiveness of the EU as an important commercial partner is still shared by most policy makers. To this day, the future of the Euro and the EU is a matter of debate among Brazilian policy makers and opinion leaders. Public opinion is divided and the media presents multiple views. On the one hand, some believe that the Eurozone is being strengthened by the current reforms. As commented by the Minister of Finance, Guido Mantega (2010), "European countries decided to make an effort to fight it, they decided to place money and develop the tools, which, in my view, are effective. They are working rapidly". From this perspective, cooperation and integration are processes that render a region stronger by providing mechanisms for collective responses to crises and problems. In this sense, the EU-model may maintain its attraction in spite of the turbulent current scenario.

On the other hand, many are convinced that a prolonged crisis will lead to further divisions within the EU, with negative repercussions 


\section{Brazil and Regional Integration in South \\ America: Lessons from the EU's Crisis}

on the sustainability of regional integration: "The truth is that Europe as a whole got into tremendous trouble. The economies of other developed countries including the US also have serious problems but the most vulnerable region is clearly Europe, both the developed and the emerging Europe" (BATISTA JR., 2010).

Lula's pronouncement on the occasion of the fourth EU-Brazil Summit in 2010 that "the successful experience of the European Union is crucial for Latin Americans, and will enrich the European Union's relations with Latin America and the Caribbean" (July 14th, 2010) suggests that the EU model of integration still holds soft power for Brazilian policy makers. Nevertheless, the Euro-crisis leaves little doubt to Brazilian observers that Europe needs increased solidarity, compromise and a rescue plan if it intends to survive united. In the context of regionalism in Latin America, caution against the perils of "too much integration" has become more common in the Brazilian narrative on Europe. How this will impact Brazil's traditional push for more integration in South America is yet unclear and will need further examination and research, some of which should undoubtedly focus on the evolution of CELAC and Brazil's participation in a new type of regionalism in South and Latin America.

\section{Notes}

1. According to Haas, the spillover is "the expansive logic of sector integration". Liberalization of trade within the customs union would lead to harmonization of general economic policies and eventually spill over into political areas and lead to the creation of some kind of political community (HAAS, 1958, p. 311). For Lindberg spillover refers to a situation in which a given action, related to a specific goal, creates a situation in which the original goal can be assured only by taking further actions, which in turn create a further condition and a need for more action, and so forth (LINDBERG, 1963, p. 10). The concept is central in the neofunctionalist approach to regional integration that became a vi- 


\section{Elena Lazarou}

brant field of research in the 1960s and gave rise to research on regional integration beyond Europe (HAAS; SCHMITTER, 1964).

2. Author's interview with Loukas Tsoukalis, Athens, January 6th, 2011.

3. These dialogues include : the EU, Gulf Cooperation Council, China, Russia, Canada, India, Japan, South Korea, ASEAN, Israel, Ukraine, Arab League, G-77, GUUAM Group (Georgia, Ukraine, Uzbekistan, Azerbaijan and Moldova), CEI, Australia, USA and the African Union. Source: Itamaraty. http://www.itamaraty.gov.br/temas/america-do-sul-e-integracao-regional/celac.

\section{References}

AGGESTAM, L. Introduction: Ethical Power Europe? International Affairs, v. 84, n. 1, p. 1-11, 2008.

AMORIM, C. Inserção Global do Brasil: OMC, Mercosul, ALCA, Zona de Livre Comércio do Brasil com a União Europeia. Lecture delivered at the XV National Forum, March 21st, 2003. Available at: <http://www.itamaraty.gov.br/sala-de-imprensa/discursos-artigos-entrevistas-e-outras-comunicacoes/ministro-estado-relacoes-exteriores/palestra-do-senhor-ministro-de-estado-das-relacoes>. Accessed on: September 30th, 2011.

Speech at the opening of the II Meeting of Supreme Courts of Mercosur. 2004a. Available at: <http://www.itamaraty.gov.br/sala-de-imprensa/discursos-artigos-entrevistas-e-outras-comunicacoes/ministro-estado-relacoes-exteriores/discurso-do-ministro-celso-amorim-na-abertura-do $>$. Accessed on: September 30th, 2011.

Declarations to the press after the Mercosur-EU Meeting. 2004b. Available at: <http://www.itamaraty.gov.br/sala-de-imprensa/discursos-artigos-entrevistas-e-outras-comunicacoes/ministro-estado-relacoes-exteriores/declaracoes-a-imprensa-do-ministro-celso-amorim>. Accessed on: September 30th, 2011.

La perspective post-crise vue du Brésil, speech given at the Institut de Sciences Politiques de Paris. Paris, France, June 12th, 2009. 


\section{Brazil and Regional Integration in South \\ America: Lessons from the EU's Crisis}

Discurso na XXVI Sessão Plenária do Parlamento do Mercosul. 2010. Available at: <http://www.itamaraty.gov.br/sala-de-imprensa/notas-a-imprensa/discurso-do-ministro-celso-amorim-na-xxvi-sessao-plenaria-do-parlamento-do-mercosul-montevideu-18-de-outubro-de-2010>. Accessed on: July $31^{\text {st }}$, 2011.

ARAVENA, F. La CELAC y la integración latinoamericana y caribeña. Nueva Sociedad, n. 240, p. 16-28, Jun.-Jul. 2012.

ASSIS, A. de; MACHADO DA COSTA JR., R. A integração regional e o governo Lula. Boletim Proealc, Centro de Ciencias Sociales (CCS), n. 19, 2003. Available at: <http://www2.uerj.br/ proealc/Boletim19.html>. Accessed on: September 30th, 2011.

BACCINI, Leonardo; DUR, Andreas. The New Regionalism and Policy Interdependence. British Journal of Political Science, v. 42, n. 1, 2012.

BALASSA, B. The Theory of Economic Integration. Illinois: R.D. Irwin, 1961.

BALDWIN, Richard. 21st Century Regionalism: Filling the Gap between 21st Century Trade and 20th Century Trade Rules. World Trade Organization, Staff Working Paper ERSD-2011-08, 2011.

BATISTA JR., P. N. Grécia, Europa e Brasil. Folha de S. Paulo, May 5th, 2010. Available at: <http://www1.folha.uol.com.br/fsp/dinheiro/fi0605201020.htm>. Accessed on: July 31st, 2011.

BELlAMY, R.; CASTIGLIONE, D. Between Cosmopolis and Community: Three Models of Rights and Democracy within the European Union. In: ARCHIBUGI, D.; HELD, D.; KÔLHER, M. (Ed.). Reimagining Political Community. Oxford: Polity Press, 1998.

BICCHI, F. Our Size Fits All: Normative Power Europe and the Mediterranean. Journal of European Public Policy, v. 13, n. 2, p. 286-303, 2006.

CAN anything perk up Europe? The Economist, July 8th, 2010a. Available at: <http://www.economist.com/node/16539326>. Accessed on: July 31st, 2011.

CEDERMAN, L. E. Constructing Europe's Identity: The External Dimension. Boulder: Lynne Riener Publishers, 2001. 


\section{Elena Lazarou}

Christie, E. Potential Trade in South-East Europe: a Gravity Model Approach. South-East Europe Review for Labour and Social Affairs, v. 85, n. 4, p. 81-101, 2002.

DESORDEM europeia. Folha de S. Paulo, March 26th, 2011. [Editorial]. Available at: <http://www1.folha.uol.com.br/fsp/indices/inde26032011.htm>. Accessed on: July 30th, 2011.

DUCHÊNE, F. Europe's Role in World Peace. In: MAYNE, R. (Ed.). Europe Tomorrow: Sixteen Europeans Look Ahead. London: Fontana, 1972. p. 32-47.

EICHENGREEN, B. Should the Maastricht Treaty Be Saved? Princeton Studies in International Finance, n. 74, 1992.

ERDOGAN, T. R. The Robust Man of Europe. Newsweek, February 17th, 2011. Available at: <http://www.newsweek.com/2011/01/17/the-robust-man-of-europe.html>. Accessed on: July 31st, 2011.

EUROPEAN COUNCIL. A Secure Europe in a Better World. Brussels: European Union, 2003. Available at: <http://www.consilium.europa.eu/uedocs/cmsUpload/78367.pdf>. Accessed on: July 31st, 2011.

Report on the Implementation of the European Security Strategy: Providing Security in a Changing World. Brussels: European Union, 2008. Available at: <http://www.eu-un.europa.eu/documents/en/081211_EU\%20Security\%20Strategy.pdf $>$. Accessed on: September 30th, 2011.

FAGUNDES, P. A América dos 33: a proposta de criação da Comunidade de Estados Latino-Americanos e Caribenhos (CELAC). Meridiano 47, v. 47, n. 116, p. 16-17, 2010.

FAWCETT, L.; HURRELL, A. (Ed.) Regionalism in World Politics. Oxford: Oxford University Press, 1995.

FIORAMONTI, L. (Ed.) Regions and Crises: New Challenges for Contemporary Regionalisms. Houndmills: Palgrave Macmillan, 2012.

FREIRE, V. T. Europa em ritmo de década perdida. Folha de S. Paulo, January 14th, 2011. Available at: <http://www1.folha.uol.com.br/fsp/mercado/me1401201114.htm>. Accessed on: September 30th, 2011.

GALLAS, D. Para analistas, Brasil em alta passa por renascimento a Europa em crise. Estado de S. Paulo, September 24th, 2010. Available at: <http://m.esta- 


\section{Brazil and Regional Integration in South America: Lessons from the EU's Crisis}

dao.com.br/noticias/nacional,para-analistas-brasil-em-alta-passa-por-renascimento-na-europa-em-crise,614768.htm>. Accessed on: September 30th, 2011.

HAAS, E. The Uniting of Europe. Stanford: Stanford University Press, 1958.

. The Study of Regional Integration: Reflections on the Joy and Anguish of Pretheorizing. International Organization, v. 24, n. 4, p. 606-646, 1963.

; SCHMITTER, P. Economics and Differential Patterns of Political Integration: Projections about Unity in Latin America. International Organization, v. 18 , n. 4, p. 705-737, 1964.

HOFFMANN, S. Obstinate or Obsolete? The Fate of the Nation-State and the Case of Western Europe. Daedalus, v. 95, n. 3, p. 862-915, 1966.

ITAMARATY. CELAC. s/d. Available at: <http://www.itamaraty.gov.br/temas/america-do-sul-e-integracao-regional/celac $>$. Accessed on: September 10th, 2013.

JARAMILlO, G. El Doble Movimiento Sudamericano: Construcción Regional y Gobernanza Global. In: ALTMANN, J.; ARAVENA, F.; BEIRUTE, T. (Ed.). América Latina y el Caribe: ¿Integrados o Marginados? Buenos Aires: FLACSO/CAF. Editorial Teseo, 2011.

KEOHANE, R.; HOFFMANN, S. Institutional Change in Europe in the 1980s. In: KEOHANE, R.; HOFFMANN, S. (Ed.). The New European Community: Decision Making and Institutional Change. Boulder: Westview Press, 1991.

KEUKELEIRE, S. The European Union as a Diplomatic Actor: Internal, Traditional and Structural Diplomacy. Diplomacy and Statecraft, v. 14, n. 3, p. 31-56, 2010.

KIM, N.; PASSONI, V. From Modern Power to a Postmodern Example: The Evolution of the European Union. International Area Review, v. 13, n. 3, p. 203-228, 2010.

LAFFAN, B. The European Union: A Distinctive Model of Internationalization. Journal of European Public Policy, v. 4, n. 2, p. 235-254, 1998.

LEITÃO, M. Não há solução definitiva à vista para a crise na Europa. CBN, July 10th, 2011.Available at: <http://oglobo.globo.com/economia/miriam/posts/2011/01/10/nao-ha-solucao-definitiva-vista-para-crise-na-europa-355615.asp>. Accessed on: July 31st, 2011. 


\section{Elena Lazarou}

LENZ, T. Problematizing the EU's Model Export to Mercosur: Strategies and Motivations. Paper prepared for the GARNET conference The European Union on International Affairs, San Francisco, 2008.

. EU Normative Power and Regionalism: Ideational Diffusion and Its Limits. Cooperation and Conflict, v. 48, n. 2, p. 211-228, 2013.

LINDBERG, L. The Political Dynamics of European Economic Integration. Stanford: Stanford University Press, 1963.

LUCARELLI, S.; MANNERS, I. (Ed.). Values and Principles in European Foreign Policy. London: Routledge, 2006.

LULA DA SILVA, L. I. Speech at the Meeting of Finance Ministers of G20. São Paulo, August 11th, 2008a. Available at: <http://www.itamaraty.gov.br/sala-de-imprensa/discursos-artigos-entrevistas-e-outras-comunicacoes/presidente-da-republica-federativa-do-brasil/703157213653-discurso-do-presidente-da-republica-luiz-inacio>. Accessed on: July 31st, 2011.

Speech at the XXXVI Summit of Mercosur's Heads of State, Bahia, December 16th, 2008b. Available at: <http://www.itamaraty.gov.br/sala-de-imprensa/discursos-artigos-entrevistas-e-outras-comunicacoes/presidente-da-republica-federativa-do-brasil/823894345013-discurso-do-presidente-da-republica-luiz-inacio>. Accessed on: July 31st, 2011.

Exclusive Interview with the President of the Federative Republic of Brazil. El Mundo, 2009. Available at: <http://www.itamaraty.gov.br/sala-de-imprensa/discursos-artigos-entrevistas-e-outras-comunicacoes/presidente-da-republica-federativa-do-brasil/969867912776-entrevista-exclusiva-concedida-por-escrito-pelo>. Accessed on: July 31st, 2011.

Remarks at the World Economic Forum, Davos, January 29th, 2010. Available at: <http://www.itamaraty.gov.br/sala-de-imprensa/discursos-artigos-entrevistas-e-outras-comunicacoes/presidente-da-republica-federativa-do-brasil/remarks-by-president-lula-at-the-world-economic $>$. Accessed on: July 31st, 2011.

MANNERS, I. Normative Power Europe: A Contradiction in Terms? Journal of Common Market Studies, v. 40, n. 2, p. 225-228, 2002.

MANTEGA, G. Crise europeia ajuda a reduzir excesso de crédito na economia do Brasil. Folha de S. Paulo, June 6th, 2010. Availabe at: <http://www.fazen- 
da.gov.br/divulgacao/entrevistas/2010/e060610>. Accessed on: July 31st, 2011.

MATTLI, W. The Logic of Regional Integration: Europe and Beyond. Cambridge: Cambridge University Press, 1999.

MORAVCSIK, A. Negotiating the Single European Act: National Interests and Conventional Statecraft in the European Community. International Organization, v. 45, n. 1, p. 19-56, 1991. 2009.

. Europe: The Quiet Super Power. French Politics, v. 7, n. 3-4, p. 403-442,

NOBODY'S backyard. The Economist, September 9th, 2010b. Available at: <http://www.economist.com/node/16990967>. Accessed on: September 31st, 2011.

NUNES, L. Parlamento do Mercosul: Utopia ou descaso? Instituto Millenium, 2010. Available at: <http://www.imil.org.br/artigos/parlamento-do-mercosul-utopia-ou-descaso/> . Accessed on: September 30th, 2011.

NYE, J. Soft Power: The Means to Success in World Politics. New York: Public Affairs, 2004.

PAIVA, F. M. Entrevista com Celso Amorim. O Estado de S. Paulo, March 16th, 2008. [Caderno Aliás, J4 e J5]. Available at: <http://www.scielo.br/scielo.php?script=sci_nlinks\&ref=000106\&pid=S0034-73292008000200009000 04\&lng=en>. Accessed on: September 30th, 2011.

PENKETH, A. Miliband: The EU Must Be a Model Power, not a Superstate. The Independent, November 16th, 2007. Available at: <http://www.independent.co.uk/news/world/europe/miliband-eu-must-be-a-model-power-not-a-superstate-400558.html>. Accessed on: July 31st, 2011.

POWERS, Kathy; GOERTZ, Gary. The Economic-Institutional Construction of Regions: Conceptualisation and Operationalisation. Review of International Studies, v. 37, n. 5, 2011.

RADIOBRÁS. Café com o presidente: Lula destaca a Unasul. 26 May 2008. Available at: <http://clipping.ebc.com.br/clipping/novo/Construtor.php?Opcao $=$ cafePresidente $\&$ tipo $=$ cafePresidente $\&$ sub $=$ sub6 $>$. Accessed on: February 13th, 2014. 
SERBIN, A. Regionalization in New Scenarios: Democratic Deficit and Civil Society Participation in South American Regionalism. Documentos CRIES, 2011. Available at: <http://www.cries.org/wp-content/uploads/2011/12/Documentos-17-ingles.pdf $>$. Accessed on: September 14th, 2013.

SJURSEN, H. What Kind of Europe? European Foreign Policy in Perspective. Journal of European Public Policy, v. 13, n. 2, p. 169-181, 2006.

SMITH, K. European Union Foreign Policy in a Changing World. Cambridge: Polity Press, 2003.

SOUTO MAIOR, L. O Brasil e o regionalismo continental frente a uma ordem mundial em transição. Revista Brasileira de Política Internacional, v. 2, n. 53, p. 42-59, 2006.

SPEKTOR, M. Ideias de ativismo regional: a transformação das leituras brasileiras da região. Revista Brasileira de Política Internacional, v. 1, n. 53, p. 25-44, 2010.

TELÒ, M. European Union and New Regionalism: Regional Actors and Global Governance in a Post-Hegemonic Era. Aldershot: Ashgate, 2007.

TORRENT, R. Regional Integration in Europe and the Americas and Bilateral Transatlantic Relations. In: GIORDANO, P. (Ed.) An Integrated Approach to the European Union-Mercosur Association. Paris: Presses de la Fondation Nationale de Sciences Politiques, 2002.

VINER, J. International Trade and Economic Development. Glencoe, Illinois: Free Press, 1952.

\section{Abstract}

\section{Brazil and Regional Integration in South America: Lessons from the EU's Crisis}

This paper introduces the idea of the EU as a 'model' of regional integration, linking it to the literature on Europe as a normative power. The second part discusses the influence of the EU model on regional 


\section{Brazil and Regional Integration in South America: Lessons from the EU's Crisis}

cooperation and integration in South America. In particular, it focuses on the discursive use of the model in Brazilian foreign policy during the two tenures of President Luis Inacio Lula da Silva as a dominant rhetoric for the promotion of regional integration, especially in the case of the Mercado Común del Sur(Common Market of the South, MERCOSUR) and the Unión de Naciones Suramericanas (Union of South American Nations, UNASUR). The last part looks at the impact of the financial crisis on the 'deconstruction' of this ideal model of European integration and attempts to discern how this will influence the future discourse on regional cooperation integration in South America, and primarily in Brazil. To illustrate the shift that has occurred in Brazilian views of regionalism, this part also discusses the Brazilian support of a new form of regional integration, as embodied in the creation of CELAC, the Community of Latin American and Caribbean States.

Keywords: Brazil - European Union - Regionalism - Mercosur - Unasur South America 